J Arid Land (2015) 7(1): 46-53

doi: $10.1007 / \mathrm{s} 40333-014-0076-7$

jal.xjegi.com; www.springer.com/40333

\title{
Long-term effects of gravel-sand mulch on soil organic carbon and nitrogen in the Loess Plateau of northwestern China
}

\author{
Yang QIU ${ }^{1}$, ZhongKui XIE ${ }^{1 *}$, YaJun WANG ${ }^{1}$, Sukhdev S MALHI ${ }^{2}$, JiLong REN ${ }^{1}$ \\ ${ }^{1}$ Cold and Arid Regions Environmental and Engineering Research Institute, Chinese Academy of Sciences, Lanzhou 730000, China; \\ ${ }^{2}$ Northeast Agricultural Research Foundation (NARF), Melfort SOE 1A0, Canada
}

\begin{abstract}
Gravel-sand mulch has been used for centuries to conserve water in the Loess Plateau of northwestern China. In this study, we assessed the influence of long-term (1996-2012) gravel-sand mulching of cultivated soils on total organic carbon (TOC), light fraction organic carbon (LFOC), microbial biomass carbon (MBC), total organic nitrogen (TON), particulate organic carbon (POC), mineral-associated organic carbon (MOC), permanganate-oxidizable carbon $\left(\mathrm{KMnO}_{4}-\mathrm{C}\right)$, and non- $\mathrm{KMnO}_{4}-\mathrm{C}$ at $0-60 \mathrm{~cm}$ depths. Mulching durations were 7,11 and 16 years, with a non-mulched control. Compared to the control, there was no significant and consistently positive effect of the mulch on TOC, POC, $\mathrm{MOC}, \mathrm{KMnO}_{4}-\mathrm{C}$ and non- $\mathrm{KMnO}_{4}-\mathrm{C}$ before 11 years of mulching, and these organic $C$ fractions generally decreased significantly by 16 years. LFOC, TON and MBC to at a $0-20 \mathrm{~cm}$ depth increased with increasing mulching duration until 11 years, and then these fractions decreased significantly between 11 and 16 years, reaching values comparable to or lower than those in the control. $\mathrm{KMnO}_{4}-\mathrm{C}$ was most strongly correlated with the labile soil $\mathrm{C}$ fractions. Our findings suggest that although gravel-sand mulch may conserve soil moisture, it may also lead to long-term decreases in labile soil organic $C$ fractions and total organic $N$ in the study area. The addition of manure or composted manure would be a good choice to reverse the soil deterioration that occurs after 11 years by increasing the inputs of organic matter.
\end{abstract}

Keywords: gravel mulch; mulching duration; permanganate-oxidizable carbon; light fraction organic carbon; microbial biomass carbon

Citation: Yang QIU, ZhongKui XIE, YaJun WANG, Sukhdev S MALHI, JiLong REN. 2015. Long-term effects of gravel-sand mulch on soil organic carbon and nitrogen in the Loess Plateau of northwestern China. Journal of Arid Land, 7(1): 46-53. doi: 10.1007/s40333-014-0076-7

The use of gravel-sand mulch is a traditional waterconservation technique that has been used for centuries in the loess region of northwestern China $(\mathrm{Li}$, 2003). A porous layer of gravel and sand about $10 \mathrm{~cm}$ thick that lies on the soil surface could reduce the risk of crop failure, which frequently occurs due to a combination of low precipitation and high evaporation that creates severe soil moisture deficits. This technique has been promoted and widely adopted due to the lack of sufficient water or high irrigation costs (Wang et al., 2011). In the Loess Plateau, the mean annual precipitation is between 250 and $350 \mathrm{~mm}$, of which nearly $70 \%$ occurs between June and September (Xie et al., 2006). The gravel-sand mulch could effectively re- duce evaporation and runoff, and increase the soil temperature and retain soil moisture (Nachtergaele et al., 1998; Wang et al., 2008, 2010; Xie et al., 2010; $\mathrm{Ma}$ and $\mathrm{Li}, 2011)$. However, the efficiency of the mulch varies widely, depending on mulch characteristics such as its color, thickness, particle size distribution and gravel texture (Fairbourn, 1973; Poesen et al., 1990; Kemper et al., 1994; Pérez, 1998, 2000; Yuan et al., 2009).

Soil organic matter (SOM) is key component of soil fertility and vegetation productivity because of its importance for soil physical, chemical and biological properties (Johnston, 1986; Stevenson, 1986; Reeves, 1997; Zhang et al., 2012). However, two soils with the

*Corresponding author: ZhongKui XIE (E-mail: wxhcas@1zb.ac.cn)

Received 2013-12-29; revised 2014-03-04; accepted 2014-06-03

(C) Xinjiang Institute of Ecology and Geography, Chinese Academy of Sciences, Science Press and Springer-Verlag Berlin Heidelberg 2015 
same SOM or SOC content may have very different properties because of differences in their SOM or SOC composition. Researchers have proposed some sensitive indicators of SOM characteristics, such as the particulate organic C (POC; Cambardella and Elliott, 1992; Christensen, 2001), light fraction organic C (LFOC; Janzen et al., 1992; Six et al., 1998, 2002) and the readily oxidizable $\mathrm{KMnO}_{4}$-extractable $\mathrm{C}$ $\left(\mathrm{KMnO}_{4}-\mathrm{C}\right.$; Blair et al., 1995; Blair and Crocker, 2000). These forms of soil $C$ respond more rapidly than bulk SOM to management-induced changes in the SOC pool, and can therefore serve as early indicators for changes in the overall $\mathrm{C}$ stock.

Although several studies have been published about the effects of gravel-sand mulch on soil water, there have been no studies on the long-term effects of gravel-sand mulch on soil organic $\mathrm{C}$ in the semiarid loess region of northwestern China. Therefore, the objective of the present study was to determine the influence of long-term use of the mulch on various components of the soil carbon stock: total organic carbon (TOC), LFOC, microbial biomass C (MBC), POC, mineral-associated organic $\mathrm{C}$ (MOC), $\mathrm{KMnO}_{4}-\mathrm{C}$ and non- $\mathrm{KMnO}_{4}-\mathrm{C}$. In addition, because of the importance of nitrogen for carbon cycling and plant growth, we also determined total organic nitrogen (TON).

\section{Materials and methods}

\subsection{Study area and sampling}

We conducted a long-term field experiment at the Gaolan Research Station of Ecology and Agriculture, Cold and Arid Regions Environmental and Engineering Research Institute, Chinese Academy of Sciences. The station is located in the northwestern Loess Plateau (Gaolan county, Lanzhou city, Gansu province; $\left.36^{\circ} 13^{\prime} \mathrm{N}, 103^{\circ} 47^{\prime} \mathrm{E}\right)$ at an altitude of approximately $1,800 \mathrm{~m}$ asl. According to 30 years of records, the mean annual precipitation totals $263 \mathrm{~mm}$, of which nearly $70 \%$ falls between May and September. The region's annual mean temperature is $8.4^{\circ} \mathrm{C}$, with the monthly mean temperature reaching a maximum of $20.7^{\circ} \mathrm{C}$ in July and a minimum of $-9.1{ }^{\circ} \mathrm{C}$ in January. The soil is a silt loam (sand $=123 \mathrm{~g} / \mathrm{kg}$; silt $=669 \mathrm{~g} / \mathrm{kg}$; clay $=208 \mathrm{~g} / \mathrm{kg}$ ) of loess origin, and belongs to the Haplic Orthic Aridisols. The pH (water) of the soil was 8.03 and measured field capacity averaged $24.5 \%$ by weight. The bulk density did not vary significantly among the plots, and averaged $1.41 \mathrm{~g} / \mathrm{cm}^{3}$ at $0-60 \mathrm{~cm}$ depths. The TOC and TON of this field in 1996 were $47.36 \mathrm{Mg} \mathrm{C} / \mathrm{hm}^{2}$ and $2,281 \mathrm{~kg} \mathrm{~N} / \mathrm{hm}^{2}$ at $0-60 \mathrm{~cm}$ depths, respectively.

The field experiment was established in 1996 at the station to investigate the long-term effects of the gravel-sand mulch. The mulch was $10 \mathrm{~cm}$ thick and was placed on the surface of the soil. It was composed of $50 \%$ gravel $(2-6 \mathrm{~cm})$ and $50 \%$ sand $(2-5 \mathrm{~mm})$ by volume. The study compared three mulching durations ( 7,11 and 16 years) with a non-mulched control. The differences of the TOC and TON mass between the control after 16 years of cultivation and the baseline value at the start of the study (1996) was not significant.

Watermelon (Citrullus lanatus) was seeded at an in-row spacing of $1.0 \mathrm{~m}$ in rows that were $0.6 \mathrm{~m}$ apart. All the treatments received $150 \mathrm{~kg}$ of $\mathrm{N} / \mathrm{hm}^{2}$ (as nitrate), $90 \mathrm{~kg}$ of $\mathrm{P}_{2} \mathrm{O}_{5}$-equivalent $/ \mathrm{hm}^{2}, 99 \mathrm{~kg}$ of $\mathrm{K}_{2} \mathrm{O}$-equivalent $/ \mathrm{hm}^{2}$ and $3,000 \mathrm{~kg}$ of raw manure (sheep) $/ \mathrm{hm}^{2}$. No irrigation was provided, so the plants relied entirely on precipitation and soil water. Each treatment had three replications, and the individual plot size was $10 \mathrm{~m} \times 10 \mathrm{~m}$. All 12 plots were randomly established in the same field, separated by $5 \mathrm{~m}$. We used the same tillage cultivation in the control plots as in the mulched plots throughout the study. Only the rows of plants were tilled between crops; the mulch was not disturbed in the between-row spaces throughout the study and most of the aboveground biomass was removed during harvesting.

The soil in all plots (below the mulch layer in the mulched plots) was sampled to a depth of $60 \mathrm{~cm}$ at 10 randomly established locations per plot in September 2012, and the samples were subdivided into subsamples for four depth layers: $0-10,10-20,20-40$ and 40-60 cm. The subsamples for each depth layer were combined to provide a single bulked sample for each plot. The samples were sieved through a 2-mm mesh to remove roots and sands. Each sample was kept in a cooler at $4^{\circ} \mathrm{C}$ at its field moisture content until analysis.

\subsection{Analysis of the soil}

TOC was determined using the wet oxidation method with $133 \mathrm{mM} \mathrm{K}_{2} \mathrm{Cr}_{2} \mathrm{O}_{7}$ at $170^{\circ} \mathrm{C}-180^{\circ} \mathrm{C}$ (Walkley and 
Black, 1934). MBC in the soil was determined using the modified chloroform fumigation-extraction method described by Gregorich et al. (1994). For LFOC, we used the density fractionation procedure described by Six et al. (1998). A suspension of 10-g soil in $25 \mathrm{~mL}$ of $\mathrm{NaI}$ solution (density of $1.8 \mathrm{~g} / \mathrm{cm}^{3}$ ) was horizontally shaken for $18 \mathrm{~h}$ at $60 \mathrm{rpm}$, and then the supernatant solution containing the light fraction was vacuumfiltered through a $0.45-\mu \mathrm{m}$ fiberglass filter that had been previously washed with $\mathrm{NaI}$ (density of $1.8 \mathrm{~g} / \mathrm{cm}^{3}$ ). The filter and the retained light fraction were rinsed with distilled water to remove NaI salt, dried at $65^{\circ} \mathrm{C}$, and weighed; then the deposited sediment was scraped from the filter, and ground with an agate mortar and pestle, and analyzed for organic $\mathrm{C}$, namely light fraction organic carbon (LFOC). To estimate the POC fraction, we added 20 -g soil to $100 \mathrm{~mL}$ of $\mathrm{Na}$ hexametaphosphate solution $(5 \mathrm{~g} / \mathrm{L})$ in a $250-\mathrm{mL}$ tube with a snap-top cap, and the mixture was then horizontally shaken for $18 \mathrm{~h}$ at $90 \mathrm{rpm}$. The soil suspension was passed through a $53-\mu \mathrm{m}$ mesh and the coarse fraction retained on the mesh was rinsed with a weak stream of distilled water, then dried at $65^{\circ} \mathrm{C}$, ground with an agate mortar and pestle, and weighed to determine POC (Cambardella and Elliott, 1992).

Blair et al. (1995) defined the fraction that was not oxidized by permanganate as non-labile. Soil samples containing $15 \mathrm{mg}$ of organic $\mathrm{C}$ (estimated based on the TOC values determined as described above) were placed in 100-mL tubes with snap-top caps and $25 \mathrm{~mL}$ of $333 \mathrm{mM} \mathrm{KMnO}_{4}$ were added. The suspensions were horizontally shaken for $1 \mathrm{~h}$ and then centrifuged at $815 \mathrm{~g}$ for $5 \mathrm{~min}$. The supernatant solution was separated, diluted with distilled water at 1:250 v/v, and then its absorbance at $565 \mathrm{~nm}$ was measured with a spectrophotometer (TU-1810, Purkinje General Instrument Co., Ltd., Beijing, China). The depletion of the $\mathrm{KMnO}_{4}$ concentration was directly related to the concentration of oxidizable $\mathrm{C}$, namely the $\mathrm{KMnO}_{4}-\mathrm{C}$ fraction, based on the assumption that $1 \mathrm{mM} \mathrm{MnO}_{4}{ }^{-}$is consumed to oxidize $0.75 \mathrm{~mol}(9 \mathrm{mg})$ of C. Luan et al. (2010) used this definition for consistency with the POC measurement, and the non-permanganate-oxidizable $\mathrm{C}$ (non- $\mathrm{KMnO}_{4}-\mathrm{C}$ ) and mineral-associated organic carbon (MOC) were calculated by subtracting $\mathrm{KMnO}_{4}-\mathrm{C}$ and POC, respectively, from TOC. TOC and other fractions $\left(\mathrm{Mg} \mathrm{C} / \mathrm{hm}^{2}\right)$ were calculated per unit area using the following equation (Matos et al., 2012):

$$
\text { Mass of } C \text { fraction }=C \times D \times T \times 0.1 \text {. }
$$

Where $C$ is the concentration of the carbon fraction ( $\mathrm{g} / \mathrm{kg}), D$ is bulk density $\left(1.41 \mathrm{Mg} / \mathrm{m}^{3}\right)$, and $T$ is the thickness of the soil layer $(\mathrm{cm})$.

Gravel-sand mulches effectively retained soil water compared with the control, but the soil water content decreased slowly (and not significantly) with increasing mulch duration (Qiu et al., 2014).

Data were subjected to analysis of variance (ANOVA), and when the results were significant, means were compared using Fisher's least-significantdifference test with significance at $P<0.05\left(\mathrm{LSD}_{0.05}\right)$.

\section{Results and discussion}

\subsection{Soil TOC}

There was usually no significant positive effect of the gravel-sand mulch on TOC in the different soil layers at $0-60 \mathrm{~cm}$ depths before 11 years of mulching, although TOC decreased slightly but significantly in the 0-10 cm soil layer after 7 and 11 years compared to the non-mulched control (Fig. 1a). TOC was highest in the control, but was only significantly higher than the TOC after 16 years. This may have resulted from decreased inputs of organic matter via plant residues such as leaf litter and fine root biomass in the mulched treatments. In the present study, the major input in the mulched treatments was root biomass because most aboveground biomass was removed during harvesting and the gravel-sand mulch layer prevented any remaining leaf and stem tissues from reaching the surface soil. TOC decreased significantly in all soil layers after 16 years of mulching, especially in the $20-40 \mathrm{~cm}$ and $40-60 \mathrm{~cm}$ layers. This reflected the decline in quality of this soil, most likely due to decrease in crop growth and change in land cover, as evidenced by the estimated crop yield in a field survey of farmers. Watermelon yields were highest after 7 years, followed closely by the yields after 11 years, which were considerably greater than yields after 16 years (data not shown), with little or no yield in the control in most years. These results are in agreement with those of Xue et al. (2011), who reported that the watermelon yield was highest after 5 years of mulching $(26,267.33$ $\mathrm{kg} / \mathrm{hm}^{2}$ ), and decreased gradually with increasing 

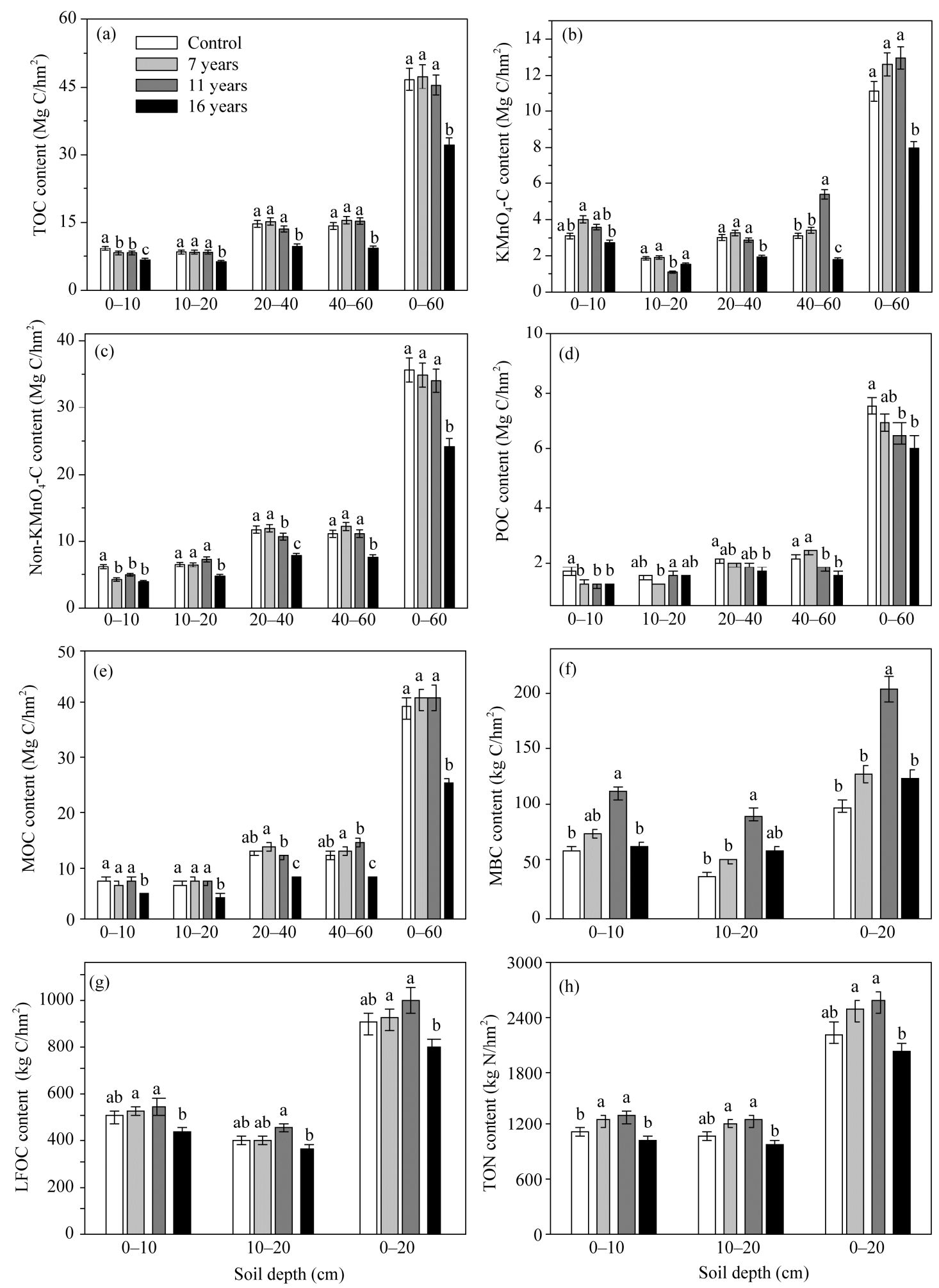

Fig. 1 Effect of gravel-sand mulch duration on the TOC (a), $\mathrm{KMnO}_{4}-\mathrm{C}(\mathrm{b})$, Non- $\mathrm{KMnO}_{4}-\mathrm{C}$ (c), POC (d), MOC (e), MBC (f), LFOC (g) and TON (h) in different soil layers in a field experiment conducted from 1996 to 2012 in Gaolan county, Lanzhou city, Gansu province, China. Bars labeled with different letters differ significantly between treatments $(P<0.05)$. Control, cropland without mulch; numbers followed by durations, cropland with that many years of gravel-sand mulch. TOC, total organic $\mathrm{C}$; $\mathrm{KMnO}_{4}-\mathrm{C}$, permanganate-oxidizable $\mathrm{C}$; $\mathrm{POC}$, particulate organic $\mathrm{C}$; MOC, mineral-associated organic $\mathrm{C}$; Non- $\mathrm{KMnO}_{4}-\mathrm{C}$, non-permanganate-oxidizable $\mathrm{C}$; MBC, microbial biomass C; LFOC, light fraction organic C; TON, total organic N. 
mulching duration; the yield after 15 years of mulching was $19.9 \%$ lower than the yield after 5 years of mulching, and the cropland soil after 20 years of mulching was characterized by an P limitation. This finding was supported by the result of root biomass: gravel mulch increased watermelon root length density (RLD) by $75 \%$ compared with the control (Xie et al., 2006). These differences might be caused by poor soil moisture conservation in the control and decreased water conservation in the mulched plots due to long-term downward movement of sand from the mulch layer into the surface soil (Wang et al., 2010). Zinn et al. (2005) reported that the soil organic carbon (SOC) concentration was directly and linearly correlated with the combined clay+silt content (but not with the clay content) at all depths. In addition, McDaniel and Munn (1985) reported a negative correlation between SOC and the sand content (20-2,000 $\mu \mathrm{m})$ in mesic Mollisols. This may also explain the decreased TOC after 16 years of mulching.

\subsection{Soil POC, MOC, $\mathrm{KMnO}_{4}-\mathrm{C}$ and non- $\mathrm{KMnO}_{4}-\mathrm{C}$}

Compared to the control, there was usually no consistent effect of the gravel-sand mulch on POC, MOC, $\mathrm{KMnO}_{4}-\mathrm{C}$ or non- $\mathrm{KMnO}_{4}-\mathrm{C}$ in the top $60 \mathrm{~cm}$ of the soil after 11 years of mulching (Fig. 1). Compared to the control, $\mathrm{KMnO}_{4}-\mathrm{C}$ decreased slightly but significantly in the 10-20 cm layer, but increased significantly in the 40-60 cm layer, whereas POC decreased significantly in the $10-20 \mathrm{~cm}$ soil layer. However, these organic $\mathrm{C}$ fractions decreased considerably after 16 years of mulching compared with the other treatments in most cases. The higher POC in the control might be related to the lack of disturbance of soil aggregates, which protect organic matter from microbial decomposition (Chen et al., 2007), whereas the slightly lower POC after 11 years may be due to the lack of inputs of plant residues during the preceding 11 years because of the removal of aboveground biomass during harvesting and the existence of the mulch layer.

Most of the TOC in the soil samples was associated with the finer soil particle sizes (i.e. $<53 \mu \mathrm{m}$ ), and POC only accounted for $8.2 \%-33.1 \%$ of TOC. In general, TOC concentrations were greater in the MOC fraction than in the POC fraction at $0-60 \mathrm{~cm}$ depths (Fig. 1), which indicates a shift of the organic matter to finer fractions during the decomposition process.
The redistribution of sand-sized organic matter to clay-complexed organic matter during decomposition was reported by Zinn et al. (2002, 2007). In agreement with these previous reports, we also found a "dilution" effect for organic $\mathrm{C}$ as a function of particle size. POC was inversely related to the mass of the particulate fraction in the soil (Fig. 2). The increased sand content in the mulched soil due to mixing of sand from the mulch layer with the topsoil after long-term mulching would obviously change this process. However, further research is necessary to clarify the mechanism responsible for this change.

\subsection{Soil LFOC}

LFOC increased in the two near-surface soil layers (0-10 and 10-20 cm) as a result of mulching, particularly after 11 years, but the increases were not significant (Fig. 1g). However, LFOC decreased dramatically and significantly between 11 and 16 years, reaching values even lower than those in the control. Researches have shown that LFOC can be strongly influenced by different land uses and that it depends mainly upon the intermediate products of the decomposition of roots and leaf litter (Laik et al., 2009). The accumulation of dead roots in the soil and of fallen leaves on the soil surface that resulted from the better crop growth permitted by moisture conservation in the mulch treatment may explain the increased LFOC (Xie et al., 2006), especially after 11 years. The significant decrease in LFOC in the two near-surface layers between 11 and 16 years may have resulted from degradation of the gravel-sand mixture due to loss of sand from the mulch layer into the surface soil during many years of cultivation. Increased exposure of organic matter that would be protected against microbial decomposition by soil aggregates caused by collapse of the aggregates during tillage can decrease LFOC (Yang et al., 2012), and this may explain the low levels of LFOC after 16 years of mulching.

\subsection{Soil MBC and TON}

$\mathrm{MBC}$ in the top $10 \mathrm{~cm}$ of the soil increased significantly after 11 years (Fig. 1f). TON in the top $20 \mathrm{~cm}$ of the mulched soil increased after 7 or 11 years of mulching, but the difference was not significant (Fig. 1h). However, both of these dynamic fractions decreased considerably (generally significantly) between 


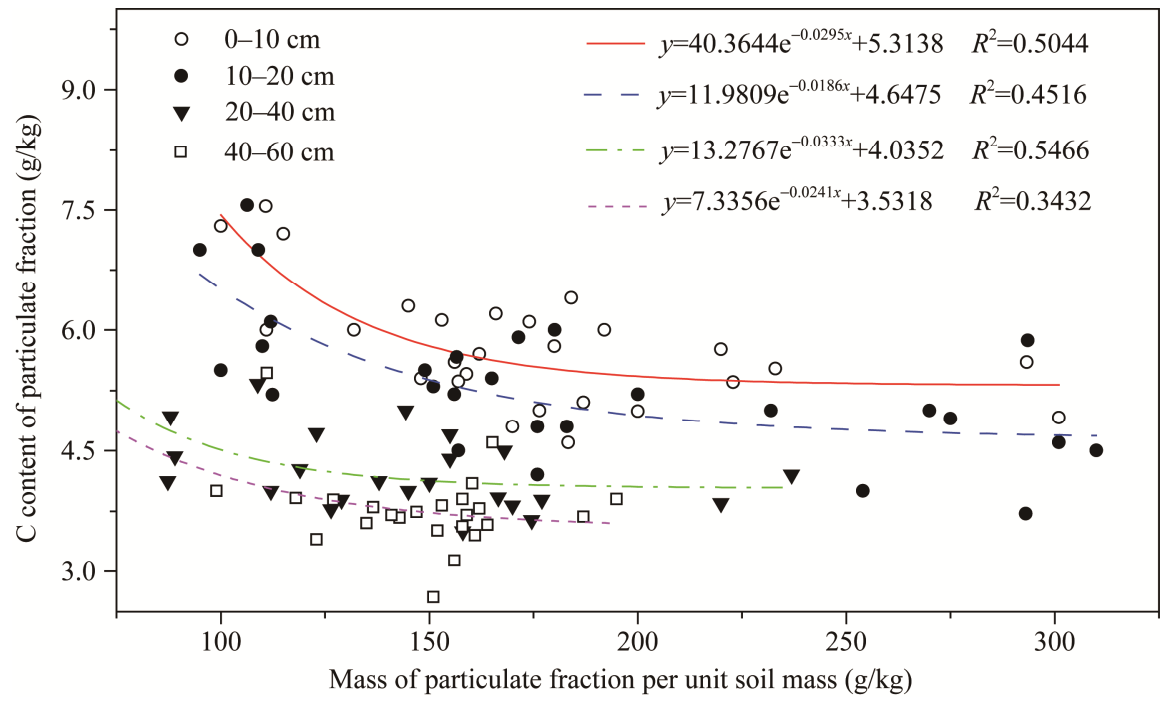

Fig. 2 The relationship between the mass of soil organic $C$ in the particulate fraction $(y)$ and the mass of this fraction per unit mass of the soil $(x)$. Values were obtained from a field experiment conducted from 1996 to 2012 in Gaolan county, Lanzhou city, Gansu province, China.

11 and 16 years, to levels comparable to those in the control. MBC in the top $10 \mathrm{~cm}$ of the soil after 16 years of mulching was close to that in the $10-20 \mathrm{~cm}$ layer. MBC reached its maximum value after 11 years and its minimum value after 16 years of mulching.

The positive effects of the gravel-sand mulch in the top $20 \mathrm{~cm}$ of the soil reflected the build-up of MBC after mulching for at least 11 years. One possible explanation for the differences in MBC between the control and the mulching treatments is that mulching increases the soil temperature (Wang et al., 2010). The higher soil temperature enhances microbial activity, thereby increasing MBC. A second possible explanation relates to the different quantity of plant residues retained between the control and mulch treatments: mulching increased watermelon root length density (RLD) by $75 \%$ compared with the control (Xie et al., 2006). The increased root residues could enter the MBC pools by providing a metabolic substrate for soil microorganisms, and would therefore increase soil MBC. However, MBC declined significantly after 16 years of mulching. This agrees with the results of Wang et al. (2010), who reported that the ability of gravel-sand mulch to increase the soil temperature decreased over time due to mixing of the gravel-sand layer with the surface soil.

TON in the two near-surface layers increased with increasing duration of mulching until 11 years, al- though the increase was not significant (Fig. 1h). This increase likely resulted from $\mathrm{N}$ inputs from the accumulation of residual roots as a result of increased root growth caused by the beneficial effects of the mulch, which also enhanced microbial activity in the soil. However, both TON and TOC decreased significantly after 16 years of mulching, thereby weakening microbial activity and decreasing MBC and TON. The decreased TON also may have resulted from the lack of nitrogen input and the high yield after 7-11 years of mulching would take more nitrogen away from the soil. In our study, the soil C:N ratio did not differ significantly among the mulching durations (data not shown), although it decreased considerably between 7 and 11 years.

\subsection{Relationships among the soil organic $\mathrm{C}$ frac- tions}

$\mathrm{KMnO}_{4}-\mathrm{C}$ was moderately to strongly correlated with the other $\mathrm{C}$ fractions $(|r|>0.451, P<0.05)$, and is thus the best overall indicator of the soil $\mathrm{C}$ status (Table 1). TOC was also strongly correlated with LFOC $(r=0.703, P<0.05)$. LFOC was strongly correlated with $\mathrm{KMnO}_{4}$-C $(r=0.768, P<0.05)$. However, weak and non-significant correlations were found between TOC and MBC and between TOC and POC, which agrees with the findings of Skjemstad et al. (2006), who also found that POC show a weak correlation with TOC compared to the strong relationship be- 
tween $\mathrm{KMnO}_{4}-\mathrm{C}$ and TOC. We found a moderate but significant correlation between $\mathrm{KMnO}_{4}-\mathrm{C}$ with POC. As in the present study, Yang et al. (2012) also found a significant correlation between $\mathrm{KMnO}_{4}-\mathrm{C}$ with MBC.

Monitoring of soil properties is crucial to identify changes caused by alternative methods of cultivation. The present results showed that under our experimental conditions, $\mathrm{KMnO}_{4}-\mathrm{C}$ and $\mathrm{LFOC}$ are the most sensitive and reliable indicators for assessing the impact of different soil management techniques on soil quality. Similarly, Zhang et al. (2007) found LFOC to be the fraction that was most sensitive to changes in soil organic $\mathrm{C}$ after the abandonment of cultivated land. Blair et al. (1995) showed that $\mathrm{KMnO}_{4}-\mathrm{C}$ was sensitive to the conversion of land use from grassland to agriculture. Because $\mathrm{KMnO}_{4}-\mathrm{C}$ is a relatively simple parameter to determine, it could be easily adopted for use in routine soil analyses.

Table 1 Correlation coefficients (Pearson's $r$ ) among various components of soil carbon stock in a field experiment conducted from 1996 to 2012 in Gaolan county

\begin{tabular}{cccccc}
\hline & TOC & POC & LFOC & $\mathrm{KMnO}_{4}-\mathrm{C}$ & $\mathrm{MBC}$ \\
\hline TOC & 1.000 & & & & \\
POC & 0.298 & 1.000 & & & \\
LFOC & $0.703^{*}$ & -0.185 & 1.000 & & \\
$\mathrm{KMnO}_{4}$-C & $0.917^{*}$ & $-0.451^{*}$ & $0.768^{*}$ & 1.000 & \\
$\mathrm{MBC}$ & 0.427 & -0.249 & $0.712^{*}$ & 0.348 & 1.000 \\
\hline
\end{tabular}

Note: soil total organic $\mathrm{C}$ (TOC), particulate organic $\mathrm{C}$ (POC), light-fraction organic $\mathrm{C}$ (LFOC), $\mathrm{KMnO}_{4}$-oxidizable $\mathrm{C}\left(\mathrm{KMnO}_{4}-\mathrm{C}\right)$ and microbial biomass $\mathrm{C}$ (MBC); ${ }^{*}$, significant at $P<0.05$.

\section{Conclusions}

In our long-term study, there was no significant and consistent positive impact of the gravel-sand mulch on soil TOC, POC, MOC, $\mathrm{KMnO}_{4}-\mathrm{C}, \mathrm{MBC}$ or $\mathrm{LFOC}$, but mulching generally increased LFOC, MBC or TON during the first 11 years. Mulching also improved the dynamic organic $\mathrm{C}$ fractions and TON in the soil until 7 or 11 years of mulching, but all the organic $\mathrm{C}$ fractions and TON declined considerably after 11 or 16 years of mulching. Among the organic $\mathrm{C}$ fractions, $\mathrm{KMnO}_{4}-\mathrm{C}$ appears to be the most sensitive overall indicator of changes in organic $\mathrm{C}$ in the mulched soil. Our findings suggest that although the use of gravelsand mulch is a promising management technique to conserve water, its ability to improve soil organic $\mathrm{C}$ may decline after 11 years of mulching in the Loess Plateau of northwestern China. One obvious way to reverse the soil deterioration that occurs after 11 years would be to increase the inputs of organic matter using manure or composted manure because these materials would also provide an input of $\mathrm{P}$ for the soil.

\section{Acknowledgments}

Funding for this research was provided by the Office of Agricultural Program, Chinese Academy of Sciences (kscx2-ewb-1-8) and the National Natural Science Foundation of China (41171027).

\section{References}

Blair G J, Lefroy R D B, Lisle L. 1995. Soil carbon fractions based on their degree of oxidation and the development of a carbon management index. Australian Journal of Agricultural Research, 46(7): 1459-1466.

Blair N, Crocker G J. 2000. Crop rotation effects on soil carbon and physical fertility of two Australian soils. Australian Journal of Soil Research, 38: 71-84.

Cambardella C A, Elliott E T. 1992. Particulate soil organic-matter changes across a grassland cultivation chronosequence. Soil Science Society of America Journal, 56: 777-783.

Chen H Q, Billen N, Stahr K, et al. 2007. Effects of nitrogen and intensive mixing on decomposition of ${ }^{14} \mathrm{C}$-labelled maize (Zea mays L.) residue in soils of different land use types. Soil and Tillage Research, 96: 114-123.

Christensen B T. 2001. Physical fractionation of soil and structural and functional complexity in organic matter turnover. European Journal of Soil Science, 52: 345-353.

Fairbourn M L. 1973. Effect of gravel mulch on crop yields. Agronomy Journal, 65: 925-928.

Gregorich E G, Carter M R, Angers D A, et al. 1994. Towards a minimum data set to assess soil organic matter quality. Canadian Journal of Soil Science, 74: 367-385.

Janzen H H, Campbell C A, Brandt S A, et al. 1992. Light fraction organic matter in soils from long term crop rotations. Soil Science Society of America Journal, 56: 1799-1806.

Johnston A E. 1986. Soil organic carbon, effects on soils and crops. Soil Use and Management, 2: 97-105.

Kemper W D, Nicks A D, Corey A T. 1994. Accumulation of water in soils under gravel and sand mulches. Soil Science Society of America Journal, 58: 56-63.

Laik R, Kumar K, Das D K, et al. 2009. Labile soil organic matter pools in a Calciorthent after 18 years of afforestation by different plantations. Applied Soil Ecology, 42(2): 71-78.

Li X Y. 2003. Gravel-sand mulch for soil and water conservation in the semiarid loess region of northwest China. Catena, 52: 105-127.

Luan J W, Xiang C H, Liu S R, et al. 2010. Assessments of the impacts of Chinese fir plantation and natural regenerated forest on soil organic matter quality at Longmen mountain, Sichuan, China. Geoderma, 
156: $228-236$.

Ma Y J, Li X Y. 2011. Water accumulation in soil by gravel and sand mulches: influence of textural composition and thickness of mulch layers. Journal of Arid Environments, 75: 432-437.

Matos E S, Freese D, Böhm C, et al. 2012. Organic matter dynamics in reclaimed lignite mine soils under Robinia pseudoacacia L. plantations of different ages in Germany. Communications in Soil Science and Plant Analysis, 43: 745-755.

McDaniel P A, Munn L C. 1985. Effect of temperature on organic carbon-texture relationships in mollisols and aridisols. Soil Science Society of America Journal, 49: 1486-1489.

Nachtergaele J, Poesen J W, Van W B. 1998. Gravel mulching in vineyards of southern Switzerland. Soil and Tillage Research, 46: $51-59$.

Pérez F L. 1998. Conservation of soil moisture by different stone covers on alpine talus slopes (Lassen, California). Catena, 33: 155-177.

Pérez F L. 2000. The influence of surface volcanic ash layers from Haleakala (Maui, Hawaii) on soil water conservation. Catena, 38: 301-332.

Poesen J, Ingelmo-Sanchez F, Mucher H. 1990. The hydrological response of soil surfaces to rainfall as affected by cover and position of rock fragments in the top layer. Earth Surface Processes and Landforms, 15: 653-671.

Qiu Y, Wang Y J, Xie Z K. 2014. Long-term gravel-sand mulch affects soil physicochemical properties, microbial biomass, and enzyme activities in the semi-arid Loess Plateau of northwestern China. Acta Agriculturae Scandinavica, Section B-Soil \& Plant Science, 64(4): 294-303.

Reeves D W. 1997. The role of soil organic matter in maintaining soil quality in continuous cropping system. Soil and Tillage Research, 43: 131-167.

Six J, Elliott E T, Paustian K, et al. 1998. Aggregation and soil organic matter accumulation in cultivated and native grassland soils. Soil Science Society of America Journal, 62: 1367-1377.

Six J, Contant R T, Paul E A. et al. 2002. Stabilization mechanisms of soil organic matter: implications for $\mathrm{C}$-saturation of soils. Plant and Soil, 241: 155-176.

Skjemstad J O, Swift R S, McGowan J A. 2006. Comparison of the particulate organic carbon and permanganate oxidation methods for estimating labile soil organic carbon. Australian Journal of Soil Research, 44: 255-263.

Stevenson F J. 1986. Carbon balance of the soil and role of organic matter in soil fertility. In: Stevenson F J, Cole M A. Cycles of Soil-Carbon, Phosphorus, Sulphur, Micro-nutrients. New York: Wiley, 45-77.

Walkley A, Black I A. 1934. An examination of the Degtjareff method for determining soil organic matter and a proposed modification of the chromic acid titration method. Soil Science, 38: 29-38.

Wang J N, Xie Z K, Guo Z H, et al. 2010. Simulating the effect of gravel sand mulched field degradation on soil temperature and evaporation. Journal of Desert Research, 30(2): 388-393. (in Chinese)

Wang Y J, Xie Z K, Malhi S S, et al. 2008. Effects of rainfall harvesting and mulching technologies on water use efficiency and crop yield in the semi-arid Loess Plateau, China. Agricultural Water Management, 96: 374-382.

Wang Y J, Xie Z K, Malhi S S, et al. 2011. Effects of gravel-sand mulch, plastic mulch and ridge and furrow rainfall harvesting system combinations on water use efficiency, soil temperature and watermelon yield in a semi-arid Loess Plateau of northwestern China. Agricultural Water Management, 101: 88-92.

Xie Z K, Wang Y J, Wei X H, et al. 2006. Impacts of a gravel-sand mulch and supplemental drip irrigation on watermelon (Citrullus lanatus [Thunb.] Mats. \& Nakai) root distribution and yield. Soil and Tillage Research, 89: 35-44.

Xie Z K, Wang Y J, Cheng G D, et al. 2010. Particle-size effects on soil temperature, evaporation, water use efficiency and watermelon yield in fields mulched with gravel and sand in semi-arid Loess plateau of northwest China. Agricultural Water Management, 97: 917-923.

Xue L, Ma Z M, Du S M. 2011. Effects of Watermelon Replanting on Yield and Quality and Soil Quality of Sandy Land. Gansu Agricuture Science and Technology, 6: 5-8. (in Chinese)

Yang X Y, Ren W D, Sun B H, et al. 2012. Effects of contrasting soil management regimes on total and labile soil organic carbon fractions in a loess soil in China. Geoderma, 177-178: 49-56.

Yuan C P, Lei T W, Mao L L, et al. Wu. 2009. Soil surface evaporation processes under mulches of different sized gravel. Catena, 78: $117-121$.

Zhang J, Song C, Wang S. 2007. Dynamics of soil organic carbon and its fractions after abandonment of cultivated wetlands in northeast China. Soil and Tillage Research, 96: 350-360.

Zhang L H, Zhong K X, Zhao R F, et al. 2012. The impact of land use change on soil organic carbon and labile organic carbon stocks in the Longzhong region of Loess Plateau. Journal of Arid Land, 4(3): 241-250.

Zinn Y L, Resck D V S, Silva J E. 2002. Soil organic carbon as affected by afforestation with Eucalyptus and Pinus in the Cerrado region of Brazil. Forest Ecology and Management, 166: 285-294.

Zinn Y L, Lal R, Resck D V S. 2005. Texture and organic carbon relations described by a profile pedotransfer function for Brazilian Cerrado soils. Geoderma, 127: 168-173.

Zinn Y L, Lal R, Bigham J M, et al. 2007. Edaphic controls on soil organic carbon retention in the Brazilian Cerrado: texture and mineralogy. Soil Science Society of America Journal, 71: 1204-1214. 